\title{
The Absent Presence: A Study of Percival in The Waves
}

\author{
Qiuxia Li \\ Foreign Languages Department, Zhengzhou University of Light Industry \\ No. 5 Dongfeng Road, Zhengzhou, Henan 450002, China \\ E-mail: daisydocument@163.com
}

Received: April 18, 2011 Accepted: May 8, 2011 doi:10.5539/ells.v1n1p77

\begin{abstract}
Percival is a character in Woolf's novel The Waves, about whom few studies have been made about because throughout the novel he is silent and absent, which makes him unnoticeable. However, in spite of his absence, he is repeatedly present in other six characters' monologues. His absent presence makes his image more mysterious and ambiguous. In a sense, he plays a most important role in the novel. He could be interpreted in different, even contradictory ways.
\end{abstract}

\section{Keywords: Percival, Absent presence, The Waves}

The Waves is a classical novel of stream of consciousness by Virginia Woolf. Throughout the novel are the interior monologues of the six characters: Bernard, Neville, Louis, Jinny, Rhoda and Susan. Apart from the six characters, there is another mysterious character, Percival, who is absent, silent, but readers can always feel his presence. He exists in the monologues of the six characters. He is absent, but always present. Why did Woolf create such a character? What is his function in the novel? To some degree he is a more important character than the other six in the novel. He can be interpreted in different ways.

\section{Percival: the Lighthouse in the Novel}

Most people think The Waves is pessimistic, but in fact, we can find a lighthouse in the novel: Percival. He was the friend of the six characters, and soon died in India, and disappeared in life. Unlike the other six characters who give continuous monologues, he is silent, he lets out no voice throughout the novel, so he is absent, but he is present in the voices of the six characters. His absence highlights his presence. He is the lighthouse in the mind of the six characters.

What's the image of Percival? Though he is absent, from the monologues of the six characters, readers can picture him. He seems to be a man with a strong figure who loves life, and is born a leader. Though he hadn't done anything great, his presence always brought hope, courage, love and harmony.

Before Percival went to India, a farewell party was held. It was a long time since the six characters graduated and they lived their own life in different places. To this end they gathered together in London, waiting for their Percival in an inn. They felt as if they would celebrate a festival. Bernard said, 'We have come together, at a particular time, to this particular spot. We are drawn into this communion by some deep, some common emotion. Shall we call it, conveniently, "love"?'(Woolf, 2000, p. 70) It is Percival who unites them together. He symbolizes some atmosphere, some hope, and some beauty. He embodies their ideal. When Percival came in, Neville felt 'My tree flowers. My heart rises. All oppression is relieved. All impediment is removed. The reign of chaos is over. He has imposed order' (Woolf, 2000, p.68). Bernard said, 'There is a red carnation in that vase. A single flower as we sat here waiting, but now a seven-sided flower, many-petalled, red, pute, purple-shaded, stiff with silver-tinted leaves-a whole flower to which every eye bring its own contribution' (Woolf, 2000, p.70). Then they calmed down and began to recall the past. Everything seemed so beautiful in their retrospection. Blackstone made the comment, 'All of them are united by the presence of Percival' (Blackstone, 1949, p. 172).

Percival represents the ideal life that the six characters long for. He lighted up their life, but soon he died. His death changed their ideal into an entire illusion. In a sense his silence could be interpreted as the absence of ideals in daily life. Learning his death, Neville felt the light of the world was extinguished. Rhoda saw all the negative sides in the world. But Bernard, the voice of the writer felt he was still somewhere. Percival died, but he remained a lighthouse in his friends' mind. His death changed his image into an eternal beauty. The life is cruel, but Percival's absent presence encourages the six characters to face life bravely. In the chaos of the world, the image of Percival expresses the writer's desire for harmony, order and love. Though in this world there are indifference, misunderstanding and 
hostility, there should be the light of ideal. Percival is absent physically, but he is present in people's deep mind. Years later when the six friends gathered together again, through their epiphany, readers can feel their desire for friendship and harmony. Percival became an eternal lighthouse in their mind.

\section{Percival: the Mirror of the Other Six Characters' Selves}

Another dominant theme of The Waves is searching for identity. The Waves exposes the fact that man and society are in a deformed and unharmonious relationship. With the development of science and technology and the advancement of industrialization, man's values also changed. Each character in the novel felt alone and alienated. The six characters don't know who they are. They are searching for their selves. Then who is Percival? In Percival the six characters saw themselves. Their selves are combined in one. Percival is anyone. He serves as the mirror of their selves.

The monologues of the six characters reveal the modern men's searching for selves. In the modern world, they felt alone. Rhoda said, 'Alone, I often fall down into nothingness. I must push my foot stealthily lest I should fall off the edge of the world into nothingness' (Woolf, 2000, p. 23). In the modern world, they don't know who they are. Rhoda didn't like looking into the looking-glass since her childhood. She said, 'I have no face. Other people have faces' (Woolf, 2000, p.23). Louis often felt he couldn't find his identity, and didn't know where he was. Jinny asked 'Who is he? Who is she?' (Woolf, 2000, p.97). Bernard also asked, 'Who am I?' (Woolf, 2000, p.162) From their monologues, we can see their loss of selves in the modern society.

Under the pressure of the modern life, people can't find the pleasure of life. Their monologues reveal their common feeling: the loss of selves. That's why in The Waves the six characters thought they had no "face", which was their identity.

In the novel the six voices hint at six selves. The six selves are separate, but at the same time are supposed to be a single, united one. They stand for six aspects of one person. The six selves are focused on an ideal figure: Percival. As the common friend of the six characters, Percival is an object they admire and worship. He is an important member of the group. However, he kept silent throughout the novel. In spite of his absence, he exists in the other six voices. Though his image can't be revealed in his own monologue, it can be imagined in the other six characters' monologues.

Why does Percival exist in the monologues of the other six characters? In fact, he embodies the selves of the other six. He is absent because he is abstract. He is not a certain person, but anybody. He serves as the mirror of the other six. He combines the selves of the other six into one. The six monologists are just the facets of one. Woolf ever wrote to G. L. Dickinson, 'I did mean that in some way we are the same person, and not separate people. The six characters were supposed to be one' (Woolf, 1978, p. 397). In the novel, Bernard ever said, 'I am not one person; I am many people; I do not altogether know who I am-Jinny, Susan, Neville, Rhoda or Louis; or how to distinguish my life from theirs' (Woolf, 2000, p.156). So in The Waves Woolf explored the collective rather than the individual aspects of identity. The six monologists all thought Percival had a stable self, so they all regarded him as their ideal self. 'He does not need a voice, because he lives in immediate, active involvement with the external world' (Apter, 1979, p. 119). He had the typical characteristics of traditional British young man. He loved sports; he had patriotism and heroism; he was willing to go to India to serve his country. His social identity is stable. In the novel his silence is a sharp contrast with the continuous monologues of the other six, which seems to suggest that he is not annoyed by his identity. His stable self was demonstrated in his ability to bring order and harmony to the group. When he appeared, Bernard said, 'There is a red carnation in that vase. A single flower as we sat here waiting, but now a seven-sided flower, many-petalled, red, pute, purple-shaded, stiff with silver-tinted leaves-a whole flower to which every eye bring its own contribution'(Woolf, 2000, p. 70) .

Percival's stable self was the ideal that the other six desired. It highlights the instability of the selves of the other six, which shows people's dilemma of building one's self in the modern world. In fact, Woolf was not praising the traditional self. Though the worship of the six characters toward Percival hints at their longing for the pre-modern living state, the impression that Percival was out of date and absurd was crystal clear. The colour of anti-hero can be found in Percival. He died in India, but not for his country, but in an accident, 'He fell, His horse tripped. He was thrown' (Woolf, 2000, p. 85).

So Percival is the mirror of the other six characters' selves. But the death of Percival threw them into a dilemma of searching for their identity in the modern society, in which they faced the problem of losing their selves.

\section{Percival: the Deconstruction of the Image of the Empire}

Percival was created by Woolf as a traditional hero: the image of the empire. But he died, which hints at the death of imperialism. In the modern world, this image is out of date. While Woolf was praising the imperialist civilization, she also satirized the stupidity and arrogance of the imperialist rulers. 
Percival is the center of the society as well as the center of the six characters. He is the representative of imperialism. In the novel, Percival never "spoke". He never revealed any consciousness. His image was broken into pieces in the monologues of the six characters. The monologues of the six characters just highlight the absence of Percival, through which Woolf's intention to deconstrcuct the image of the British empire can be detected.

As a hero in his friends' mind, Percival died soon after he got to India, but ironically, he died in an accident, not for the country, so his image of hero was deconstructed. His death signals the fall of the imperialist regime.

Percival's pointless death shows the absurdity of the image. He is the representative of imperialism, but also the victim to the regime. Bernard said, 'I should be able to place him in trifling and ridiculous situations, so that he may not feel himself absurd, perched on a great horse. I must be able to say, "Percival, a ridiculous name" (Woolf, 2000, p.86). His absurdity and pointless death deconstructed the image of the empire.

\section{Percival: the Invisible Shadow, the Inevitable Death}

Death is a haunting theme in Woolf's works. In The Waves, death is embodied in the absent figure: Percival. He was silent, he was absent, but he was present in the other six characters' monologues. He was always present. He exists as an invisible shadow to remind the six others of the inevitable death. Percival's death intensifies the truth of the inevitability of death. Death, as a contrast with life, is what every mortal being must face.

The German philosopher, Heidegger, thinks the greatest possibility for man is death. He examines death and life on the same level. He thinks that life is life that heads for death. Only when man has a clear understanding of death can he understand the meaning and value of life. Only when man is brave enough to face death can he create the beauty of life in the limited life.

The Waves is a novel exploring death as well as life. It presents the journey of life of the six characters moving from childhood to adulthood, to old age, and to death. In the interludes before each part there are the descriptions of nature. The changes from the sunrise to the sunset in a day symbolize the different stages in life. 'I am writing to a rhythm and not to a plot' (Woolf, 1978. p. 204), Woolf stated of The Waves. The Waves conveys the rhythm of life in synchrony with the cycle of nature and the passage of time. The rise and fall of the waves is just the rhythm of human existence. Death is part of the cycle of birth, life, death and resurrection.

Death is invisible, but it is there. Present in the monologues of the six characters is the absent Percival. He made them aware of the inevitability of death. Rhoda said, 'Oh, life, how have I dreaded you' (Woolf, 2000, p.115). Death is combined with life. "Such is the incomprehensible combination," said Bernard, "such is the complexity of things, that as I descend the staircase I do not know which is sorrow, which joy. My son is born; Percival is dead" (Woolf, 2000, p. 85). Jinny sighed, 'Life comes, life goes' (Woolf, 2000, p. 98). Neville regarded the first death he heard about as 'death among the apple trees'(Woolf, 2000, p. 12). He realized that 'But we are doomed, all of us, by the apple trees, by the immitigable tree which we cannot pass' (Woolf, 2000, p. 12). In face of death, man shouldn't escape. At the end of the novel, Bernard cried, 'It is death against whom I ride with my spear couched and my hair flying back like a young man's, like Percival's, when he galloped in India. I strike spurs into my horse. Against you I will fling myself, unvanquished and unyielding, O Death!'(Woolf, 2000, p. 167) He expressed the desire of man to surpass death, which is inevitable.

The death of Percival, the six characters' loved friend, made them realize the truth: no one can escape death. The vast sea in The Waves attached a new meaning to death. Death is not the end of life, but the sublimation of life. Woolf had been searching for the true meaning of death all her life and put it into practice. Finally, she chose to drown herself to illustrate the beauty of death.

\section{Conclusion}

Percival, an absent character in The Waves, is present in his special way. He exists in his friends' monologues. His absence highlights his presence, and increases the mystery and ambiguity of the image. He could be interpreted in different and even contradictory ways. He is the lighthouse in the novel; he is the mirror of the six characters' selves; he embodies the deconstruction of the empire; he embodies the inevitable death of man.

\section{References}

Apter, T. E. (1979). Virginia Woolf: A Study of her Novels. London and Basingstoke: The Macmillan Press Ltd.

Blackstone, Bernard. (1949).Virginia Woolf: A Commentary. London: The Hogarth Press.

Woolf, Virginia, (1978) A Reflection of the Other Person: The Letters of Virginia Woolf, Vol 4:1929-31, Hogarth Press, London.

Woolf, Virginia. (2000). The Waves. Hertfordshire: Wordsworth Editions Limited. 